\author{
새로운 비황분계 부취제 혼합 LPG 연료의 엔진성능과 \\ 배출가스 특성에 관한 연구 \\ 김재곤 ${ }^{\dagger}$ 임의순 · 민경일 · 정충섭 \\ 한국석유관리원 석유기술연구소 \\ (2014년 7월 21일 접수, 2014년 9월 11일 수정, 2014년 9월 15일 채택)
}

\title{
A Study on the Performance and Exhaust Emissions Characteristics of LPG Engine using LPG Fuel with New Sulfur Free Odorant
}

\author{
Jae-Kon Kim · Eui Soon Yim · Kyong-il Min · Choong-sub Jung \\ Research Institute of Petroleum Technology, Korea Petroleum Quality \& Distribution Authority(K-Petro)
}

(Received 21 July 2014, Revised 11 September 2014, Accepted 15 September 2014)

요약

일반적으로 황분계 부취제는 연료가스에 인한 가스중독, 발화, 폭발 등의 사고를 방지하고, 배출가 스에 의해 연료 가스 누출의 즉각적으로 손쉽게 검출할 수 있도록 $\mathrm{LPG}, \mathrm{LNG}$ 그리고 도시가스와 같은 연료가스에 첨가 사용하고 있다. 본 연구에서는 새로운 비황분계 부취제(K-Petro S-Free)를 사용 한 $\mathrm{LPG}$ 혼합연료의 엔진 성능과 배출가스 $\left(\mathrm{CO}, \mathrm{THC}, \mathrm{CO}_{2}, \mathrm{NO}_{\mathrm{x}}, \mathrm{SO}_{2}\right)$ 특성을 살펴보았다. 새로운 비황분계 부취제를 $40 \mathrm{mg} / \mathrm{kg}$ 를 혼합한 $\mathrm{LPG}$ 연료(여름용, 겨울용)와 현재 사용 중인 황분계 부취제 (EM, ethyl mercaptan)를 혼합한 LPG 연료의 엔진 성능과 배출가스 특성을 실험하였다. 비황분계 부취제를 혼합한 LPG 연료의 엔진 성능은 황분계 부취제를 혼합한 LPG 연료와 비교할 때 비슷한 결과를 보여 주었다. 한편, 비황분계 부취제를 혼합한 LPG 연료의 엔진 배출가스 중 $\mathrm{CO}, \mathrm{THC}, \mathrm{CO}_{2}$, $\mathrm{NO}_{\mathrm{x}}$ 은 황분계 부취제를 혼합한 LPG 연료와 비교할 때 비슷한 특성을 보였다. 그러나 2,000rpm에서 배출가스 중 $\mathrm{SO}_{2}$ 은 비황분계 부취제를 혼합한 $\mathrm{LPG}$ 연료가 황분계 부취제를 혼합한 $\mathrm{LPG}$ 연료보다 $83 \%$ 감소하는 우수한 결과를 보였다.

\section{주요어 : 비황분계 부취제, LPG 연료, 배출가스}

\begin{abstract}
In general, odorants are added to fuel gases, such as LPG, LNG and city gas, to prevent gas poisoning, ignition, explosion, or other accident caused by fuel gases, and to enable immediate and easy detection of fuel-gas leakage by emitting an offensive smell. This study describes a study on the performance and exhaust emissions $\left(\mathrm{CO}, \mathrm{THC}, \mathrm{CO}_{2}, \mathrm{NO}_{\mathrm{x}}, \mathrm{SO}_{2}\right.$ ) characteristics of liquefied petroleum gas (LPG) engine using LPG fuel with new sulfur free odorant (K-Petro S-Free). New sulfur free odorant $(40 \mathrm{mg} / \mathrm{kg}$ ) was added to 2 type LPG fuels for summer, and winter and it was used in performance and exhaust emissions, compare to LPG fuel with sulfur containing odorant (EM, ethyl mercaptan). Engine performance using LPG with sulfur free odorant was similar to LPG with sulfur-containing odorant. Exhaust emissions (CO, THC, $\mathrm{CO}_{2}, \mathrm{NO}_{\mathrm{x}}$ ) of LPG with sulfur free odorant were also similar characteristics, compare with sulfur containing odorant. Especially, $\mathrm{SO}_{2}$ emission using LPG with K-Petro S-Free odorant was more reduced 83 \% than LPG with sulfur containing odorant(EM) at $2000 \mathrm{rpm}$.
\end{abstract}

\footnotetext{
${ }^{\dagger}$ To whom corresponding should be addressed.

Research Institute of Petroleum Technology, Korea Petroleum Quality\&Distribution Authority, 33, Yangcheong 3-gil, Ochang-eup, Cheongwon-gu, Cheongju-si, Chungcheongbuk-do, 363-883, Korea Tel : 043-240-7933 E-mail : jkkim@kpetro.or.kr
} 
Key words : sulfur free odorant, LPG fuel, emission gas

\section{1. 서 론}

최근 친환경 연료 및 신재생에너지 확대 보급에 따 라 국내 자동차용 휘발유, 경유 및 액화석유가스 (Liquefied Petroleum Gas, LPG) 등 수송용 연료의 법상 품질기준 내 황분 함량도 저황분화 또는 Sulfur free $(10 \mathrm{mg} / \mathrm{kg})$ 추세이다[1]. 따라서 국내 자동차 보 급의 급격한 증가에 따른 대도시의 대기환경오염을 해결하기 위해 1990년 대기환경보전법이 개정되어 대기오염물질 저감을 위한 자동차 연료 제조기준이 도입되었다. 이에 따라 국내에서도 1991년부터 자동 차 연료에서 기인하는 오염물질을 줄이기 위해 자동 차용 휘발유 및 경유에 대해 품질기준을 강화하였다. 특히, 국내 자동차용 $\mathrm{LPG}$ 의 품질기준은 2000년 10 월에 처음으로 제정되었으며, $\mathrm{LPG}$ 연료 내의 황분 품질기준[2]은 초기 $2,000 \mathrm{ppm}$ 이하로 제한되었지만, 단계적으로 강화되어 2009 년부터 $40 \mathrm{ppm}$ 이하로 규 정하고 있다.

$\mathrm{LPG}$, 도시가스, 공업용 가스 또는 천연가스 (natural gas) 등의 연료가스는 냄새가 적기 때문에 이것들은 누설되어도 감지할 수 없고, 인화, 폭발 또 는 중독 등의 재해를 일으키는 우려가 있었다. 이러 한 연료가스 누출이 발생할 경우 그것을 인간의 후각 으로 용이하게 감지하고 사고를 미연에 방지하기 위 하여 부취제가 첨가되고 있다[3-4]. 현재 국내에서 사 용되고 있는 LPG 부취제는 황분계인 EM (Ethyl mercaptan), CP 630 (Methylethyl sulfide, Dimethyl sulfide, tert-Butyl Mercaptan) 吕 vigileak 7030 (Dimethyl sulfide, tert-Butyl Mercaptan) 등의 비점 이 높고 기화성이 낮은 황 화합물들을 사용하고 있다 [5-6]. 이들 부취제는 대부분 황화합물로 구성되어 있 어, $\mathrm{LPG}$ 에 첨가 시 추가로 황 함량을 증가시키고 있 다. 이러한 황분계 부취제는 연료가스에 첨가되어 폭 넓게 사용되고 있으나, 황 화합물인 부취제에서 기인 된 황분이 대기 중으로 아황산(sulfur dioxide)로 배 출되어 대기오염의 원인이 되고 있으며, 차량의 연료 시스템과 연료공급 시설에서 금속부식을 초래 할 수 있다. 또한, 연료전지 등의 $\mathrm{LPG}$ 를 사용하는 새로운 기기 등이 개발되고 있는데 종래의 황분계 부취제를 사용할 경우 부취제를 제거해야 하는 문제점을 안고
있다[7-9]. 따라서 이러한 문제점을 극복할 수 있는 황이 포함되어 있지 않은 비황분계 부취제의 개발에 대한 필요성이 대두되고 있으며, 현재 유럽 및 일본 등에서 개발하고 있거나 사용되고 있다[10]. 이러한 흐름에 따라 국내에서도 기존 황분계 부취제를 대체 할 수 있는 LPG 용 비황분계 부취제가 개발[11]되어 이미 $\mathrm{LPG}$ 연료에 대한 적용성 평가가 이루어졌다. 한편, 개발된 새로운 비황분계 부취제가 기존 황분계 부취제를 대체하기 위해서는 LPG 연료에 첨가하여 차량 엔진에 대한 적용성 연구가 필요하다. 즉, 비황 분계 부취제를 사용한 LPG 연료의 기존 차량 엔진의 성능과 배출가스의 영향성 검증이 필요 하는 것이다.

따라서 본 연구에서는 자동차용 LPG 연료에 첨가 하여 사용할 수 있는 비황분계 부취제를 개발하여 엔 진동력계와 FT-IR 분광법[12-14]. 을 이용하여 새로 운 비황분계 부취제를 첨가한 $\mathrm{LPG}$ 연료에 대한 $\mathrm{LPG}$ 엔진성능과 배출가스 특성을 살펴보았다.

\section{2. 실험장치 및 방법}

\section{2-1. 부취제 및 LPG 연료의 조성}

실험에 사용한 황분계 부취제인 $\mathrm{EM}$ (Ethyl mercaptan)은 시약급 순도 $97 \%$ 로 시그마알드리치 코 리아에서 구입하여 사용하였다. Methyl isovalerate은 시약급 순도 $99 \%$ 로 시그마알드리치 코리아에서 구입 하였고, methyl acrylate, 2-ethyl-3-methyl pyrazine 은 각각 시약급 순도 $99 \%$ 로 $\mathrm{TCI}$ 에서 구입하여 사용 하였다. 실험에 사용된 비황분계 부취제는 K-Petro S-Free로 명명하고, methyl isovalerate, methyl acrylate, 2-ethyl-3-methyl pyrazine의 3가지를 혼합 하여 제조하였다. Table 1에서 비황분계 부취제인 K-Petro S-Free를 구성하고 있는 부취물질(odorant) 들의 물리화학적 특성을 보이고 있다. Table 1 과 Fig. 1 의 3 가지 부취물질로 이루어져 있는 비황분계 부취제 K-Petro S-Free는 무색투명한 액체로 평균 분 자량은 108 , 비중은 $0.58\left(15^{\circ} \mathrm{C}\right)$, 인화점은 $7^{\circ} \mathrm{C}$, 증기 압은 $79{ }^{\circ} \mathrm{C}\left(25^{\circ} \mathrm{C}\right)$ 등의 물성을 지니고 있다. 또한, methyl isovalerate : methyl acrylate (99\%) : 2-ethyl-3-methyl pyrazine의 혼합 조성비는 $50 \%$ : 
Table 1. Physical and chemical property of K-Petro S-Free

\begin{tabular}{c|c|c|c|c}
\hline No. & Odor materials & b.p $\left({ }^{\circ} \mathrm{C}\right)$ & status & $\begin{array}{c}\text { blending } \\
\text { ratio(\%) }\end{array}$ \\
\hline \hline 1 & $\begin{array}{c}\text { Methyl } \\
\text { isovalerate }\end{array}$ & 116.16 & liquid & 50 \\
\hline 2 & Methyl acrylate & 80.35 & liquid & 40 \\
\hline 3 & $\begin{array}{c}\text { 2-Ethyl-3-methy } \\
\text { 1 pyrazine }\end{array}$ & 120 & liquid & 10 \\
\hline
\end{tabular}

Table 2. Composition of LPG fuel in experimental

\begin{tabular}{c|c|c}
\hline $\begin{array}{c}\text { Compositions } \\
(\text { mol \%) }\end{array}$ & $\begin{array}{c}\text { Base LPG for } \\
\text { summer }\end{array}$ & $\begin{array}{c}\text { Base LPG for } \\
\text { winter }\end{array}$ \\
\hline \hline Ethane & & 0.42 \\
\hline Propane & 1.3 & 23.17 \\
\hline iso-Butane & 49.5 & 27.14 \\
\hline n-butane & 49.2 & 48.44 \\
\hline iso-butene & & 0.26 \\
\hline iso-Pentane & & 0.57 \\
\hline
\end{tabular}

Table 3. List of LPG fuels with odorant in experimental

\begin{tabular}{c|c|c|c|c}
\hline No. & $\begin{array}{c}\text { Odorant } \\
\text { type }\end{array}$ & $\begin{array}{c}\text { Summer } \\
\text { LPG }\end{array}$ & $\begin{array}{c}\text { Winter } \\
\text { LPG }\end{array}$ & $\begin{array}{c}\text { Addition } \\
\text { amounts of } \\
\text { odorant }\end{array}$ \\
\hline \hline 1 & & $\begin{array}{c}\text { Base } \\
\text { LPG }^{\mathrm{a}}\end{array}$ & ${\text { Base } \text { LPG }^{\mathrm{a}}}$ & \\
\hline 2 & Sulfur & $\begin{array}{c}\mathrm{EM}^{\mathrm{b}}+ \\
\text { Base LPG }\end{array}$ & $\begin{array}{c}\mathrm{EM}+\text { Base } \\
\text { LPG }\end{array}$ & $40 \mathrm{wt} \mathrm{ppm}$ \\
\hline 3 & $\begin{array}{c}\text { Sulfur } \\
\text { free }\end{array}$ & $\begin{array}{c}\text { K-Petro } \\
\text { S-Free } \\
\text { Base LPG }\end{array}$ & $\begin{array}{c}\text { K-Petro } \\
\text { S-Free }+ \\
\text { Base LPG }\end{array}$ & $40 \mathrm{wt}$ ppm \\
\hline
\end{tabular}

${ }^{a}$ No addition odorant, ${ }^{b} \mathrm{EM}$ : Ethyl mercaptan,

${ }^{\mathrm{c}} \mathrm{K}$-Petro S-Free : mixtures of 3 odorants as non-containing sulfur compound

Table 4. Test engine specifications

\begin{tabular}{l|l}
\hline \multicolumn{1}{c|}{ Model } & \multicolumn{1}{|c}{ Theta LPi engine } \\
\hline \hline Type & LPi injection \\
\hline Valve mechanism & L4KA-14DOHC \\
\hline Cooling & Water cooling \\
\hline Number of cylinder & 4 \\
\hline Diameters of cylinder $(\mathrm{mm})$ & 86 \\
\hline Capacity $(\mathrm{cc})$ & 1,998 \\
\hline Max. Power $(\mathrm{ps} / \mathrm{rpm})$ & $141 / 6000$ \\
\hline Max. Torque $(\mathrm{kg} \cdot \mathrm{m} / \mathrm{rpm})$ & $19.0 / 4250$ \\
\hline Rated speed (rpm) & 750 \\
\hline Fuel supply type & LPG injector
\end{tabular}

$40 \%: 10 \%$ 이다. 실험에 사용된 $\mathrm{LPG}$ 연료는 $\mathrm{LPG} 2$

호 (자동차용)로 여름용 및 겨울용 조성으로 제조 되었으며 그 조성을 Table 2에 나타내었다. Table 2 의 조성으로 제조된 여름용 및 겨울용 바탕 $\mathrm{LPG}$ 연

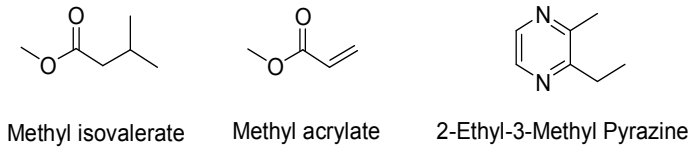

Fig. 1. Structure of Sulfur free odorants

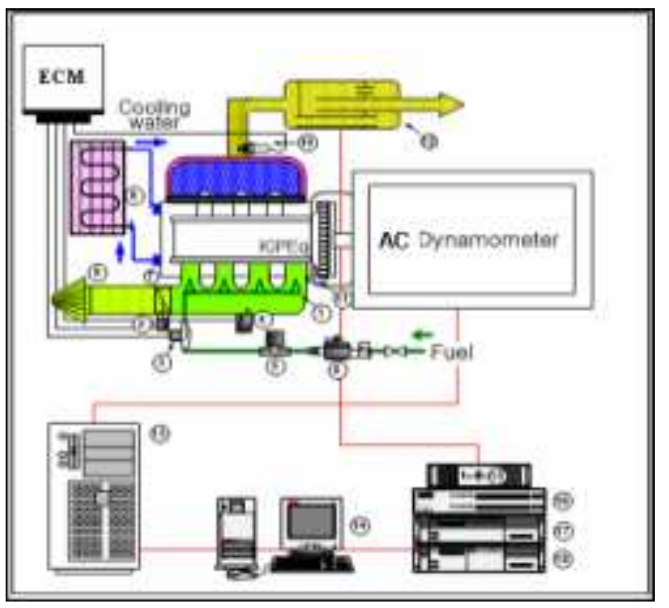

1.Injector, 2.Throttle actuator, 3.Fuel Pressure, 4.Map sensor, 5.MFC, 6.Fuel cot-off V/V, 7.Throttle position sensor, 8.Cooling water, 9.Air cleaner, $10 . \mathrm{O} 2$ sensor, 11.Start motor, 12.Muffler, 13.Dynamometer controller, 14.Data processor, 15.Intake pressure analyzer, 16. Lambda meter, 17.Exhaust gas analyzer, 18.FT-IR analyzer

Fig. 2. Schematic of the experimental test rig.

료에 황분계 부취제인 $\mathrm{EM}$ 과 새로운 비황분계 부취 제인 K S-Free를 각각 $40 \mathrm{wt} \mathrm{ppm}$ 씩 첨가하였으며 본 연구에서 사용된 여름용과 겨울용의 LPG 연료 조 성을 Table 2에 나타내었다.

\section{2-2. 실험용 엔진}

새로운 비황분계 부취제를 첨가한 LPG 연료에 대 한 LPG 엔진성능과 배출가스 연구에 사용된 엔진 제 원을 Table 4에 나타내었다. 실험엔진은 배출량이 $1,998 \mathrm{cc}$ 이며, 4행정 4실린더 $\mathrm{DOHC}$ 엔진이고, 연료 분사방식은 $\mathrm{LPG}$ 액상 분사(LPi) 방식이다.

\section{2-2. 엔진 동력계 및 측정장비}

본 연구의 엔진성능 및 배출가스 측정을 위한 실 험장치의 전체적인 개략도를 Fig. 2에 나타내었다. 실 험용 엔진의 크랭크축과 동력계를 직결로 연결하여 부하를 제어하고 토크를 측정하였으며, 냉각수 및 엔 진오일 온도조절 공급 장치를 통하여 엔진에 들어가 


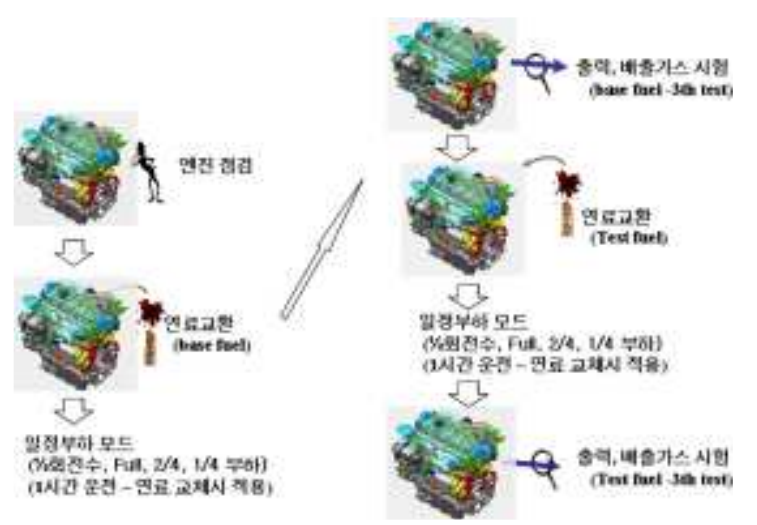

Fig. 3. Test procedures for engine performance and exhaust emissions

는 냉각수는 $85 \pm 2^{\circ} \mathrm{C}$, 오일은 $95 \pm 2^{\circ} \mathrm{C}$ 의 동일조건으로 제어하여 공급하였다. 또한, 연료량 및 연료 온도 조 절장치를 장착하여 엔진의 실험조건에 따라 연료량을 실시간으로 측정하였다.

엔진의 흡기 및 배출관에는 각각의 측정영역에 알 맞은 압력센서를 이용하여 압력을 계측하였고, 냉각 수 온도 센서, TPS(Throttle position sensor), 공기량 및 온도, 흡기관 절대압력 센서(MAP sensor), 광대역 산소센서(O2 sensor) 등을 엔진에 설치하여 실험조건 에 따른 각 부의 상태를 정하였다. 취득된 데이터는 데이터 취득 장치를 통해 컴퓨터에 저장하였다. 배출 관에는 배출가스 배출물의 농도를 측정할 수 있는 배
출가스 분석기(FID, ND-IR, CLD 방법)와 FT-IR 분 석기를 사용하여 규제물질과 미규제 물질의 배출가스 농도를 동시에 계측하였다.

Fig. 3 과 같은 실험 절차로 전체적인 엔진성능과 배출가스 실험을 실시하였으며, 모든 실험은 정확도 를 고려하여 3 회 실시하였다. 각각의 엔진운전 실험 조건에 따라 엔진의 출력, 토크, 연료소모률 그리고 배출가스 $\left(\mathrm{CO}, \mathrm{THC}, \mathrm{CO}_{2}, \mathrm{NO}_{\mathrm{x}}\right.$ 및 $\left.\mathrm{SO}_{2}\right)$ 특성 등을 파악하였고, 실험은 부취제 미첨가 바탕(base) LPG 연료를 먼저 측정하고 황분계 부취제 (EM) 혼합 LPG (여름용, 겨울용) 그리고 비황분계 부취제 (K-Petro S-Free) 혼합 LPG 연료(여름용, 겨울용) 순 으로 측정하였다.

\section{3. 결과 및 고찰}

\section{3-1. 연료물성 및 실험결과}

Table 5에서는 바탕 (base) LPG 연료의 여름용 및 겨울용에 황분계 부취제 $(\mathrm{EM})$ 와 새로운 비황분계 부취제(K-Petro S-Free)를 각각 $40 \mathrm{wt} \mathrm{ppm}$ 넣고 항 목별 품질평가 결과를 보여주고 있다. 「액화석유가스 의 안전관리 및 사업법 의 액화석유가스 품질기준[2] 을 모두 만족하였다. Table 5에서 비황분계 부취제 K-Petro S-Free 혼합에 따라 여름용과 겨울용 LPG

Table 5. Properties of winter LPG with Odorants of EM and K-Petro S-Free

\begin{tabular}{|c|c|c|c|c|c|c|c|c|c|}
\hline \multirow{2}{*}{\multicolumn{2}{|c|}{$\begin{array}{l}\text { Class } \\
\text { Item }\end{array}$}} & \multicolumn{2}{|c|}{ Standard } & \multicolumn{3}{|c|}{ Summer LPG } & \multicolumn{3}{|c|}{ Winter LPG } \\
\hline & & summer & Winter & $\begin{array}{l}\text { Base } \\
\text { LPG }\end{array}$ & $\mathrm{EM}^{\mathrm{a}}+\mathrm{LPG}$ & $\begin{array}{c}\text { K-PetroS-Free } \\
\text { +LPG }\end{array}$ & Base LPG & $\mathrm{EM}^{\mathrm{a}}+\mathrm{LPG}$ & $\begin{array}{l}\text { K-PetroS- } \\
\text { Free }^{\text {b }} \\
+ \text { LPG }\end{array}$ \\
\hline \multirow{3}{*}{$\begin{array}{l}\text { Compos } \\
\text { ition } \\
(\mathrm{mol} \%)\end{array}$} & $\begin{array}{c}\text { C3- } \\
\text { Hydrocarbon } \\
\end{array}$ & $\begin{array}{c}\max . \\
10\end{array}$ & $25 \sim 35$ & 1.39 & 1.39 & 1.38 & 21.48 & 21.47 & 21.47 \\
\hline & $\begin{array}{c}\text { C4- } \\
\text { Hydrocarbon }\end{array}$ & $\begin{array}{c}\max . \\
85\end{array}$ & $\begin{array}{c}\min . \\
60\end{array}$ & 98.61 & 98.61 & 98.62 & 78.52 & 78.53 & 78.53 \\
\hline & Butadiene & $\max$ & 0.5 & - & - & - & - & - & - \\
\hline \multicolumn{2}{|c|}{ Sulfur Content (mg/kg) } & $\max$. & 400 & $2.34^{\mathrm{c}}$ & 2.34 & 2.34 & $3.52^{\mathrm{c}}$ & 3.52 & 3.52 \\
\hline \multicolumn{2}{|c|}{$\begin{array}{l}\text { Vapor pressure }(40 \\
\left.{ }^{\circ} \mathrm{C}, \mathrm{kPa}\right)\end{array}$} & $\max$. & 1.27 & 0.44 & 0.43 & 0.44 & 0.57 & 0.58 & 0.57 \\
\hline \multicolumn{2}{|c|}{$\begin{array}{c}\text { Density } \\
\left(15{ }^{\circ} \mathrm{C}, \mathrm{kg} / \mathrm{m}^{3}\right)\end{array}$} & 500 & 620 & 576.0 & 576.2 & 576.1 & 562 & 562 & 562 \\
\hline \multicolumn{2}{|c|}{ Residue (ml) } & \multicolumn{2}{|c|}{$\max .0 .05$} & $\begin{array}{c}\max . \\
0.05\end{array}$ & $\begin{array}{c}\max . \\
0.05\end{array}$ & $\max .0 .05$ & $\max .0 .05$ & $\max .0 .05$ & $\begin{array}{c}\max . \\
0.05\end{array}$ \\
\hline \multicolumn{2}{|c|}{$\begin{array}{c}\text { Copper strip corrosion } \\
\left(40^{\circ} \mathrm{C}, 1 \mathrm{~h}\right)\end{array}$} & \multicolumn{2}{|c|}{$\max .1$} & $\max .1$ & $\max .1$ & $\max .1$ & $\max .1$ & $\max .1$ & $\max .1$ \\
\hline
\end{tabular}

$\mathrm{a}, \mathrm{b}$ 부취제 첨가량은 각각 $40 \mathrm{wt} \mathrm{ppm}$ 임

c부취제 미첨가 바탕시료(base LPG)의 황 함량임 


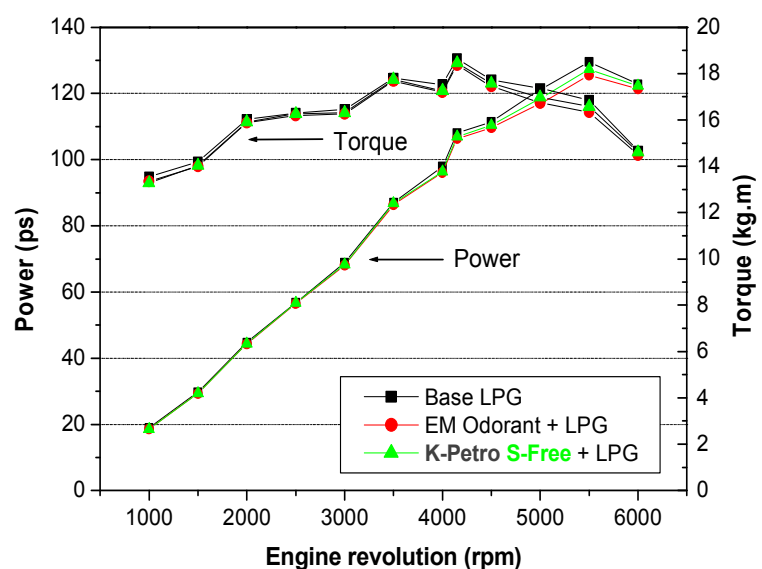

Fig. 4. Power and torque for summer LPG with odorants of EM and K-Petro S-Free

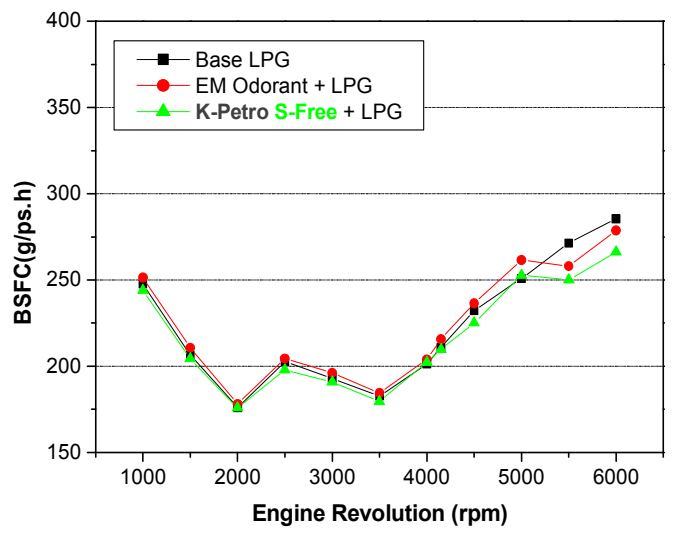

Fig. 6. BSFC for summer LPG with odorants of EM and K-Petro S-Free in full load

연료의 조성에는 오차범위 내로 큰 변화가 없었다. 또한, LPG 연료의 조성 이외 황 함량, 증기압, 밀도, 잔류물질 그리고 동판부식의 5 개 항목에도 큰 영향 없이 현행 LPG 연료의 품질기준을 모두 만족하고 있 음을 알 수 있다. 특히 황 함량에 있어 바탕시료(base $\mathrm{LPG})$ 의 여름용과 겨울용 황 함량은 각각 2.35 $\mathrm{mg} / \mathrm{kg}, 3.53 \mathrm{mg} / \mathrm{kg}$ 이었는데, 황 성분을 갖지 않는 비 황분계 부취제 K-Petro S-Free 첨가에 따라 황 함량 이 변화가 없음을 알 수 있다.

\section{3-2. 엔진 성능특성}

비황분계 부취제 (K-Petro S-Free) 첨가 LPG 연료 를 사용한 엔진성능 실험은 현재 사용 중인 황분계 부취제 $(\mathrm{EM})$ 를 첨가한 여름용과 겨울용 $\mathrm{LPG}$ 연료에 대한 엔진성능에 대한 특성을 파악하고자 실시하였 다. Fig. 4과 Fig. 5는 전부하(full load) 조건에서 출

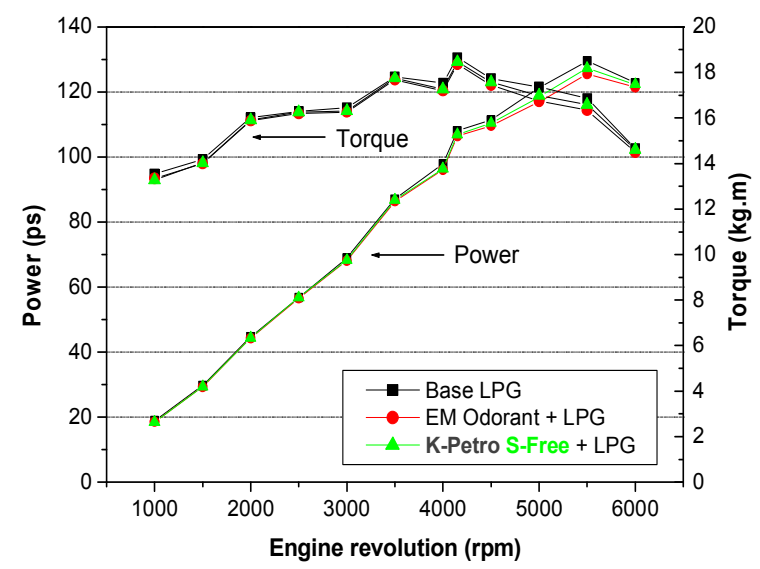

Fig. 5. Power and torque for winter LPG with odorants of EM and K-Petro S-Free in full load

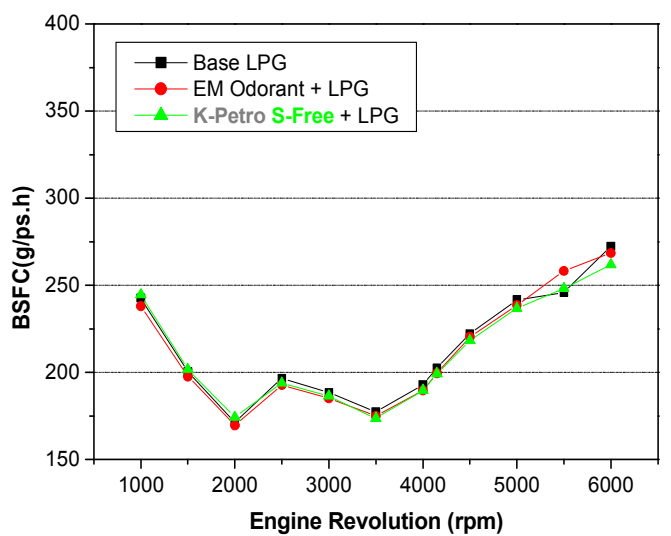

Fig. 7. BSFC for winter LPG with odorants of EM and K-Petro S-Free in full load

력과 토크에 대한 엔진성능 실험 결과를 나타냈으며, Fig. 6와 Fig. 7도 역시 전부하(full load) 조건에서 연료소모률(BSFC, brake specific fuel consumption) 에 대한 엔진성능 실험 결과를 나타내었다.

엔진출력, 토크 및 엔진소모률에 대한 엔진성능 실험 결과, 비황분계 부취제를 첨가한 $\mathrm{LPG}$ 연료는 현행 황 분계 부취제와 비교해 볼 때 거의 비슷한 결과를 나타 내었다. 특히, 연료소모률(BSFC)은 비황분계 부취제 를 첨가한 여름용 및 겨울용 LPG 연료가 현행 황분계 부취제를 첨가한 여름용 및 겨울용LPG 연료보다 고속 구간인 $5,000 \mathrm{rpm}$ 이상에서 조금 낮게 측정되었다. 이 러한 결과로 볼 때 현행 LPG 차량에 도입하여 사용하 여도 엔진성능에는 큰 문제가 없을 것으로 판단된다.

\section{3-3. 배출가스 특성}

비황분계 부취제 (KiPEq S-Free)를 첨가한 여름용 


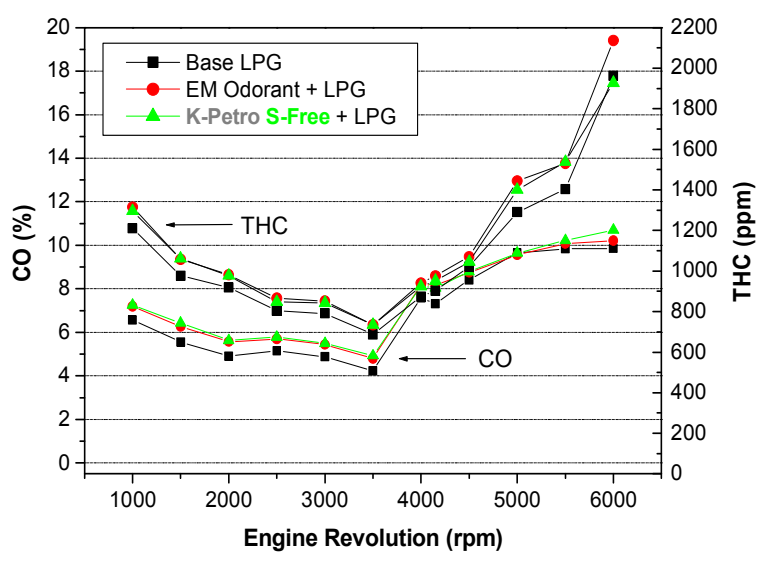

Fig. 8. CO, THC emissions for summer LPG with odorants of EM and K-Petro S-Free in full load

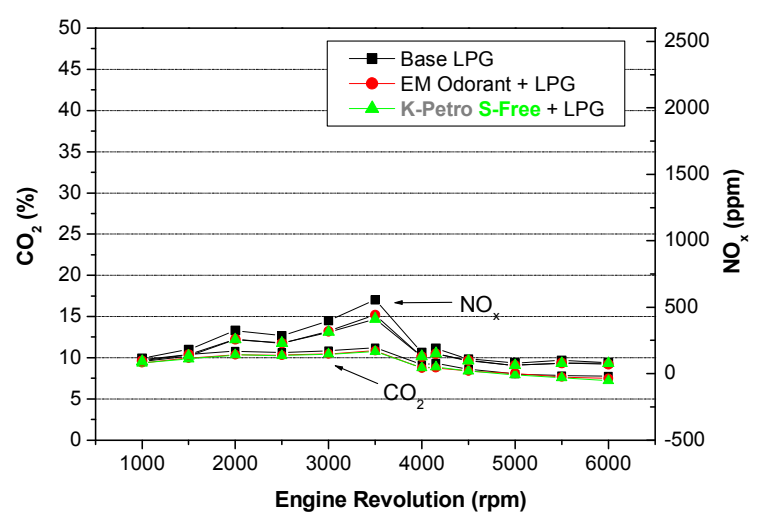

Fig. 10. $\mathrm{CO}_{2}, \mathrm{NO}_{\mathrm{x}}$ emissions for summer $\mathrm{LPG}$ with odorants of EM and K-Petro S-Free in full load

및 겨울용 $\mathrm{LPG}$ 연료에 대한 배출가스 $(\mathrm{CO}, \mathrm{THC}$, $\mathrm{CO}_{2}, \mathrm{NO}_{\mathrm{x}}$ 및 $\mathrm{SO}_{2}$ )는 $1,000 \mathrm{rpm}$ 부터 $6,000 \mathrm{rpm}$ 까지 측정하여 현행 황분계 부취제 $(\mathrm{EM})$ 첨가 여름용 및 겨울용 LPG 연료의 배출가스를 서로 비교하였다. 측 정원리는 대기환경보전법 제작 자동차 실험 방법에 근거하여 $\mathrm{CO}$ 및 $\mathrm{CO}_{2}$ 는 비분산적외선 분석법 (NDIR, Nondispersive infrared), THC는 열식불꽃이 온화 검출기법 (HFID, Heated frame ionization detector), $\mathrm{NO}_{\mathrm{x}}$ 는 화학발광법 (CLD, Chemiluminescence detector) 그리고 $\mathrm{SO}_{2}$ 는 FT-IR 분석법에 의한 결과이다. 특히 황 성분을 함유하지 않은 비황분계 부취제 첨가 $\mathrm{LPG}$ 연료의 $\mathrm{SO}_{2}$ 배출가 스는 황을 함유한 황분계 부취제 첨가 $\mathrm{LPG}$ 연료에 비해 이론적으로 저감효과를 주며, 대기 환경적 측면 에서 중요한 결과가 될 수 있다.

Fig. 8과 Fig. 9는 전부하(full load) 조건에서 $\mathrm{CO}$,

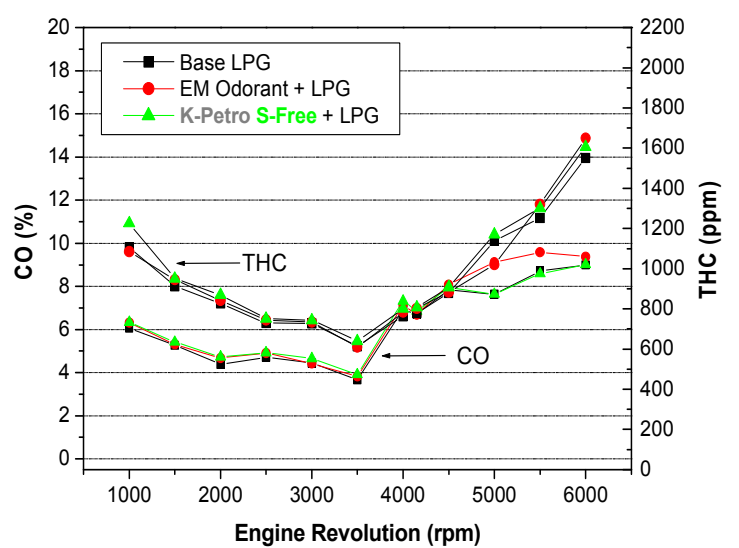

Fig. 9. $\mathrm{CO}, \mathrm{THC}$ emissions for winter LPG with odorants of EM and K-Petro S-Free in full load

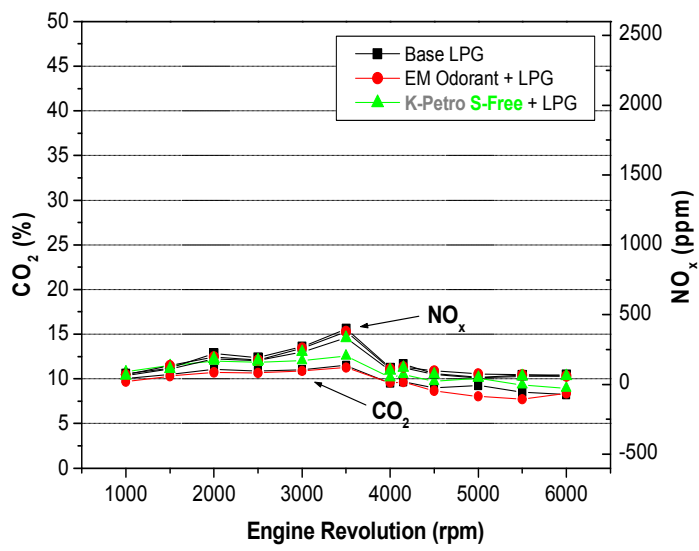

Fig. 11. $\mathrm{CO}_{2}, \mathrm{NOx}$ emissions for winter $\mathrm{LPG}$ with odorants of EM and K-Petro S-Free in full load

$\mathrm{THC}$ 에 대한 배출가스 실험 결과이며, Fig. 10과 Fig. 11 도 역시 전부하(full load) 조건에서의 $\mathrm{CO}_{2}, \mathrm{NO}_{\mathrm{x}}$ 에 대한 배출가스 실험 결과이다. $\mathrm{CO}, \mathrm{THC}, \mathrm{CO}_{2}$, 및 $\mathrm{NO}_{x}$ 에 대한 배출가스 실험 결과, 비황분계 부취제 (KiPEq S-Free)를 첨가한 여름용 및 겨울용 LPG 연 료는 황분계 부취제 $(\mathrm{EM})$ 와 비교해 볼 때 실험 오차 범위 내에서 거의 비슷한 결과를 나타내고 있다.

또한, 본 연구에서 비황분계 부취제를 첨가한 $\mathrm{LPG}$ 연료의 $\mathrm{SO}_{2}$ 배출가스 저감 효과를 알아보기 위한 실 험 은 $1000 \mathrm{rpm}$ 부터 $6000 \mathrm{rpm}$ 까지 전부하(full load) 조건에서 FT-IR로 분석하였으며 실험 결과는 Fig. 12과 Fig. 13에 나타내었다. $\mathrm{SO}_{2}$ 배출가스 실험 결과, 전부하(full load) 조건에서 비황분계 부취제를 첨가한 여름용 및 겨울용 $\mathrm{LPG}$ 연료가 황분계 부취제 를 첨가한 $\mathrm{LPG}$ 연료에 비해 $\mathrm{SO}_{2}$ 배출가스가 각각 $59 \%$ (여름용), $66 \%$ (겨울용) 저감되었다. 이러한 결 


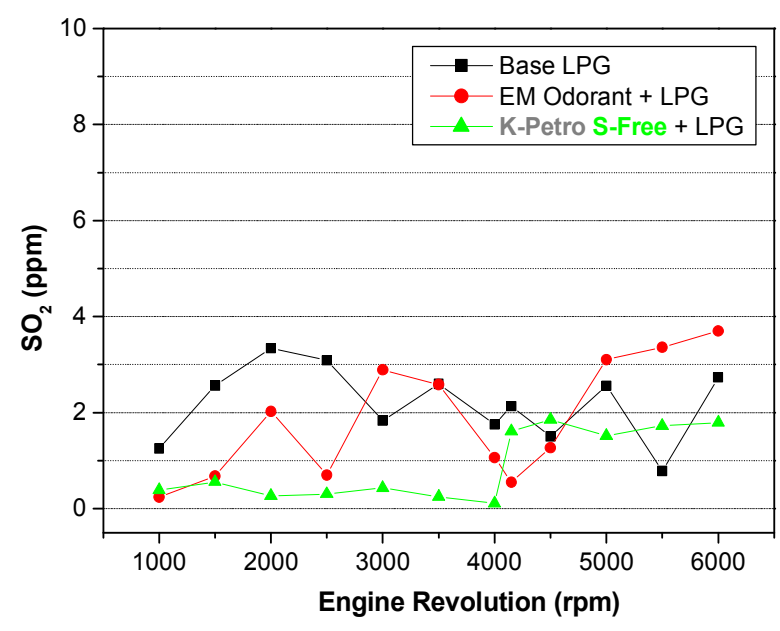

Fig. 12. $\mathrm{SO}_{2}$ emission for summer LPG with odorants of EM and K-Petro S-Free in full load

과는 황이 포함되지 않은 비황분계 부취제에 대한 효 과로 실제 차량에 적용될 경우 대기 중 $\mathrm{SO}_{2}$ 배출가스 저감에 기여할 것으로 판단된다.

$2000 \mathrm{rpm}$ 에서 비황분계 부취제를 첨가한 여름용 및 겨울용 $\mathrm{LPG}$ 에 대한 부하별 $\mathrm{SO}_{2}$ 배출가스는 황분 계 부취제와 비교하여 Fig. 14에 나타내었다. 전 부 하별 비황분계 부취제를 첨가한 여름용 및 겨울용 $\mathrm{LPG}$ 연료는 황분계 부취제에 비해 $\mathrm{SO}_{2}$ 배출가스는 각각 $83 \%, 43 \%$ 감소하였다. 비황분계 부취제는 겨 울용 LPG 연료보다 부탄 주성분인 여름용 LPG 연료 에서 $\mathrm{SO}_{2}$ 배출가스 감소 효과가 더 컸다.

\section{4. 결론}

LPG 엔진동력계와 FT-IR spectroscopy를 이용하 여 새로운 비황분계 부취제를 첨가한 LPG 연료에 대 한 LPG 엔진성능과 배출가스 특성을 평가한 결과 다 음과 같은 결과를 얻을 수 있었다.

1) 엔진성능 특성을 살펴보면, 비황분계 부취제 (K-Petro S-Free)를 첨가한 여름용 및 겨울용 $\mathrm{LPG}$ 연료는 황분계 부취제 (EM)와 비교해 볼 때 실험 오차 범위 내에서 거의 비슷한 결과를 보여주었다.

2) $\mathrm{SO}_{2}$ 배출가스 실험 결과, 전부하(full load) 조 건에서 비황분계 부취제를 첨가한 여름용 및 겨울용 LPG 연료가 황분계 부취제를 첨가한

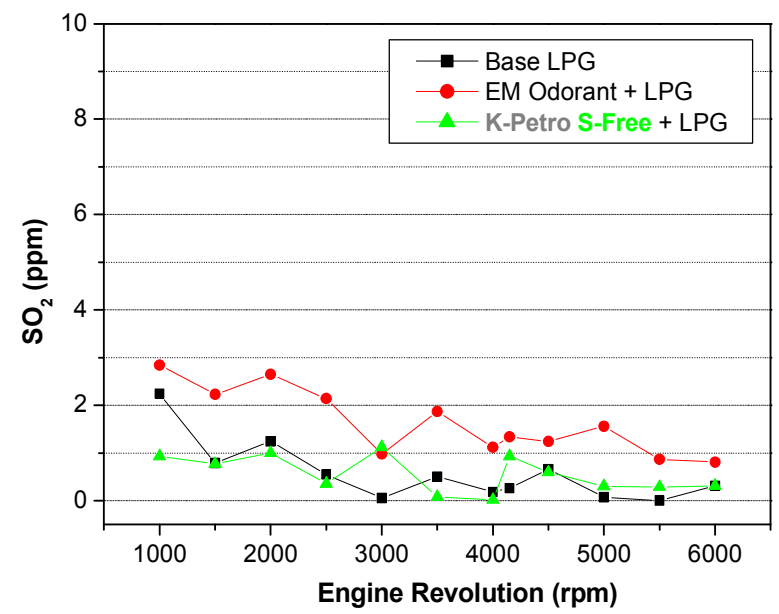

Fig. 13. $\mathrm{SO}_{2}$ emission for winter $\mathrm{LPG}$ with odorants of EM and K-Petro S-Free in full load

$\mathrm{LPG}$ 연료에 비해 $\mathrm{SO}_{2}$ 배출가스가 각각 $59 \%$ (여름용), $66 \%$ (겨울용) 저감되었다.

3) $2000 \mathrm{rpm}$ 에서 전 부하별 비황분계 부취제를 첨 가한 여름용 및 겨울용 $\mathrm{LPG}$ 연료는 황분계 부 취제에 비해 $\mathrm{SO}_{2}$ 배출가스는 각각 $83 \%, 43 \%$ 저감되었다. 비황분계 부취제는 겨울용 $\mathrm{LPG}$ 보 다 부탄 주성분인 여름용 $\mathrm{LPG}$ 에서 $\mathrm{SO}_{2}$ 배출가 스 저감효과가 더 컸다.

4) 비황분계 부취제 (K-Petro S-Free)를 첨가한 $\mathrm{LPG}$ 연료의 $\mathrm{SO}_{2}$ 배출가스 저감은 황을 함유하 지 않은 부취제의 효과로 설명될 수 있다.

5) 새로운 비황분계 부취제를 첨가한 LPG 연료에 대 한 LPG 엔진성능과 배출가스 특성을 평가한 결 과로 비황분계 부취제(K-Petro S-Free)는 기존 사 용 중인 황분계 부취제를 대체하여 LPG 차량 엔 진에 적용하여 사용할 수 있을 것으로 사료된다.

$$
\text { 감사의 글 }
$$

본 연구는 산업통상자원부의 “중소형 LPG 상 용차 기술개발" 사업의 일환으로 지원되어 수행되었 으며, 관계자 여러분께 진심으로 감사드립니다.

\section{References}

1. Thérèse, $\mathrm{S}$ and Elena, L., "Overcoming barriers to the implementation of alternative 
fuels for road transport in Europe", 2008, Journal of Cleaner Production, 16, 577-590.

2. Fuel quality standard of LPG in Korea, Korea Petroleum Quality \& Distribution Authority, 2014, http://www.kpetro.or.kr/sub.jsp?MenuID=m2as402

3. Arthur, R. K and Arun, V., "Measurement of Odorant Levels in Natural Gas", 1976, Ind. Eng. Chem., Prod. Res. Dev., 15(1), 59-63.

4. Marvin, L. W., John, W. G., Faye, O. C and Dennis, W. B., "Odorant Evaluation : A Study Ethanthiol and Tetrahydrothiophene as Waring agents in Propane", 1978, Environmental Science \& Technology, 12(12), 1285-1288.

5. De Wild, P. J., Nyqvist, R. G., De Bruiji, F. $A$ and Stobbe, E. R., "Removal of sulphur-containing odorants from fuel gases for fuel cell-based combined heat and power applications", 2006, Journal of Power Sources, 159, 995-1004.

6. Lee, S. H., Song, T. Y., Baek and Y. S., "Optimization of Odor Concentration by Operation of Small Station Odorizer”, 2001, KIGAS, 5(3), 36-44.

7. Frank, G., Kerstin, $\mathrm{K}$ and Rainer, R., "Sulfur-Free Odorization with Gasodor S-Free-a Aeview of the Accompanying Research and Development Activities", Energy \& Fules, 2007, 21, 3322-3333.

8. Imamura, D., Akai, M and Watanabe, S., "Exploration of Hydrogen Odorants for Fuel Cell Vehicles", 2005, Journal of Power Sources, 152, 226-232.

9. Cui, H., Tum, S. Q and Reese, M. A., "Removal of sulfur compounds form utility pipelined synthetic natural gas using modified activated carbons", 2009, Catalysis Today, 139, 274-279.

10. Ruzsanyi, V., Sielemann, S and Baumbach, J. I., "Detection of sulfur-free odorants in natural gas using ion mobility spectrometry", 2007, Journal of Environmental Monitoring, 9, 61-65.
11. Kim, J. K., Park, C. K., Yim, E. S and Kim, D. K, 2009, "The Compositions of Sulfur Free Odorant", Korea Patent, Patent No.100933493.

12. Stephen R. Lowry et al., "The measurement of exhaust emissions from oxygenated fuel blends by fourier transform infrared spectroscopy.", 1995, SAE Paper No.950220,

13. Chung, S. H and Han, S. M "A study on the exhaust emission of LPG and gasoline vehicle.", 2002, Transactions of KSAE, 10(5), pp.23-28.

14. Kim, J. H., Lee, M. H., Park, J. B., Kim, S. W., Song, H. Y., Kim, J. G and Shin, S.-C., "A study on the characteristics fo engine and vehicle performance and exhaust emission for legal and illegal diesel fuel", 2006, Transactons of KSAE, 9(1), 648-653. 